\title{
PENGARUH REKRUTMEN, PENGATURAN STAF DAN PENGEMBANGAN KARIER TERHADAP KINERJA KARYAWAN
}

\author{
Muhammad Nurdin \\ Sekolah Tinggi Ilmu Manajemen Indonesia (STIMI) Banjarmasin \\ muhammadnurdin1986@gmail.com
}

\begin{abstract}
The development of tertiary education is now facing a lot of attention, especially in the current condition where there is obligation to work at least at undergraduate education level. Good quality employees are hired to advance education. So it is necessary to assess employee performance through a study conducted at the Indonesian College of Management (STIMI) Banjarmasin. This research uses quantitative research techniques. The sample is same as population, which is all existing employees (lecturers and academic staff) because of small population (overall). Data collection techniques are through statements distributed in the questionnaire. Data is analyzed by linear regression analysis. Recruitment, staffing and career developments in this study are in accordance with the real and present phenomena. When the recruitment, staffing and career developments are conducted well, it is expected to create good performances also. Therefore, it will make this institution survive sustainably in the future.
\end{abstract}

Keywords: Recruitment, Staff Arrangement, Career, Performance.

\section{PENDAHULUAN}

\section{I.1 Latar Belakang}

Kinerja memiliki makna yang sangat besar atas keberadaan suatu organisasi atau perusahaan. Kinerja sebagai perlambangan bentuk pemertahanan atas persaingan luas. Definisi dari kinerja atau prestasi kerja adalah hasil kerja secara kualitas dan kuantitas yang dicapai oleh seorang pegawai dalam melaksanakan tugasnya sesuai dengan tanggung jawab yang diberikan kepadanya (Mangkunegara, 2006:67).

Kemudian agar organisasi berfungsi secara efektif dan sesuai dengan sasaran organisasi, maka organisasi harus memiliki kinerja karyawan yang baik yaitu dengan melaksanakan tugas-tugasnya dengan cara yang handal (Simamora, 1997:339). Lalu oleh Mangkuprawira dan Hubeis (2007:153), mengemukakan bahwa kinerja karyawan adalah hasil dari proses pekerjaan tertentu secara berencana pada waktu dan tempat dari karyawan serta organisasi bersangkutan. Kinerja juga didefinisikan sebagai seperangkat hasil yang dicapai dan merujuk pada tindakan pencapaian serta pelaksanaan sesuatu pekerjaan yang diminta (Stolovitch and Keeps, 1992). Ada lagi kinerja adalah salah satu kumpulan total dari kerja yang ada pada diri pekerja (Griffin, 1987). Kinerja merupakan suatu fungsi dari motivasi dan kemampuan. Untuk menyelesaikan tugas atau pekerjaan seseorang harus memiliki derajat kesediaan dan tingkat kemampuan tertentu. Kesediaan dan ketrampilan seseorang tidaklah cukup efektif untuk mengerjakan sesuatu tanpa pemahaman yang jelas tentang apa yang akan dikerjakan dan bagaimana mengerjakannya (Hersey and Blanchard, 1993).

Ada pula pengertian kinerja merujuk pada tingkat keberhasilan melaksanakan tugas serta kemampuan mencapai tujuan yang telah ditetapkan. Kinerja dinyatakan baik dan sukses jika tujuan yang diinginkan dapat tercapai dengan baik (Donelly, Gibson and Ivancevich, 1994). Kinerja sebagai kualitas dan kuantitas pencapaian tugas-tugas, baik yang dilakukan oleh individu, kelompok maupun perusahaan (Schermerhorn, Hunt and Osborn, 1991). Kinerja merupakan fungsi interaksi antara kemampuan $($ Ability $=\mathrm{A})$, motivasi (motivation $=\mathrm{M})$ dan kesempatan $($ Opportunity $=\mathrm{O})$ atau Kinerja $=$ $f(\mathrm{~A} \times \mathrm{M} \times \mathrm{O})$; artinya: kinerja merupakan fungsi dari kemampuan, motivasi dan kesempatan 
(Robbins,1996). Kinerja adalah hasil kerja yang dicapai seseorang dalam melaksanakan tugastugasnya atas kecakapan, usaha dan kesempatan.

Berdasarkan paparan diatas kinerja adalah suatu hasil yang dicapai seseorang dalam melaksanakan tugas-tugas yang didasarkan atas kecakapan, pengalaman dan kesungguhan serta waktu menurut standar dan kriteria yang telah ditetapkan sebelumnya (Hasibuan, 2002:160)

Dari beberapa pengertian kinerja menurut para ahli tersebut dapat disimpulkan bahwa kinerja karyawan adalah hasil kerja yang dilakukan oleh seseorang dalam suatu organisasi agar tercapai tujuan yang diiginkan suatu organisasi dan meminimalisir kerugian. Atau kinerja adalah kesediaan seseorang atau kelompok orang untuk melakukan sesuatu kegiatan dan menyempurnakannya sesuai dengan tanggung jawabnya dengan hasil seperti yang diharapkan.

Di lapangan, yaitu di perusahaan atau organisasi di mana kinerja menjadi tolak ukur bagaimana seseorang atau bagian tertentu mengerjakan sesuatu. Misal, seorang pegawai pada perusahaan industri perakitan mobil yang dipekerjakan di bagian pemasangan mobil, maka yang dinilai tentu adalah penampakan dari benda (ban) yang ia pasang. Bukan dari mobil yang ada dibuat oleh bagian lainnya. Kinerjanya pun dapat diukur dari bagaimana cara kerjanya, apakah sudah sesuai prosedur, sudah sesuai dengan jenis mobilnya, sudah diuji ketahanan bannya dan lainnya.

Contoh lain, seorang guru yang bekerja dengan mengajar di suatu sekolah dapat dinilai kinerjanya melalui profil pendidikan sebelumnya, pengalaman yang sudah dilaluinya, prestasi apa saja yang sudah diraihnya, dan yang lainnya. Bahkan ada teknik penilaian tersendiri untuk mengukur kinerja guru tersebut yang diatur oleh pemerintah melalui peraturan dan perundang-undang yang berlaku. Kedua contoh tersebut memiliki tempat, jenis, karakteristik, cara dan subjek pekerjaan yang berbeda tetapi sama-sama dapat diukur kinerja berdasarkan masing-masing cara penilaian sesuai dengan cirinya masing-masing. Untuk karyawan perusahaan dapat berupa lembaran Daftar Penilaian Prestasi Pegawai dan guru melalui Sasaran Kinerja Guru (PKG) yang sekarang dikembangkan bahkan sudah digunakan secara dalam jaringan (online) melalui Peraturan Menteri Negara Pendayagunaan Aparatur Negara dan Reformasi Birokrasi Nomor 16 Tahun 2009 tentang Jabatan Fungsional Guru dan Angka Kreditnya.

Kinerja sangat penting diteliti karena kinerja adalah suatu hasil atau produk dari proses panjang dari pengelolaan organisasi atau perusahaan. Melalui adanya kinerja dapat terlihat bahwa perusahaan atau organisasi masih hidup tidaknya, dapat terlihat kemajuan dan kemampuannya dalam bersaing dengan kompetitornya.

Robbins \& Coultler, (2010:270) menjelaskan bahwa rekrutmen adalah proses melokasikan, mengidentifikasi dan menarik para pelamar kerja yang kompeten. Dapat diartikan bahwa proses rekrutmen tidak hanya sekejap saja pelaksanaannya. Ada melalui beberapa tahapan tertentu yang harus dilalui. Kebanyakan perusahaan atau organisasi yang berpengalaman dan sudah besar memiliki program rekrutmen yang bagus dan ketat dalam menyaring para calon karyawannya.Hal ini untuk menjaga keutuhan perusahaan atau organisasi itu sendiri.

Pada penelitian Ambar Teguh Sulistiyani (2003), didapati bahwa kinerja adalah kombinasi dari kemampuan, usaha dan kesempatan yang dapat dinilai dari hasil kerjanya, pengertian tersebut menunjukkan bahwa kemampuan akan berpengaruh secara langsung terhadap kinerja yang akan di hasilkan oleh karyawan. Kondisinya sekarang, kinerja secara tidak langsung bertautan dengan proses rekrutmen karena dengan adanya proses pada kegiatan rekrutmen, menjadikan hasil dari proses tersebut berupa sumber daya manusia yang sudah tersaring melalui berbagai tahapan rekrutmen tersebut menjadi tenaga kerja atau karyawan yang handal dan dapat diandalkan. Namun tidak semua perusahaan atau organisasi melakukan proses rekrutmen tersebut secara baik dan benar, bahkan ada yang membuat proses rekrutmen tersebut hanya sebatas formalitas saja. Seperti layaknya membeli ikan tanpa melihat kondisinya langsung. Dari teori dan penelitian sebelumnya yang sudah ada dapat digambarkan bahwa rekrutmen memegang peranan penting dalam proses menuju kinerja karyawan yang diinginkan.

Pada penelitian yang dilakukan oleh Fadilah, dkk. di tahun 2013) juga oleh Wijaya \& Suana di tahun yang sama, didapati bahwa staffing atau penempatan karyawan mempengaruhi kinerja karyawan. Hal ini sangat mendukung kenyataan di mana karyawan yang dalam keadaan senang bekerja dalam lingkungan kerja yang pas dapat memotivasi karyawan untuk bekerja lebih giat. Penempatan karyawan (staffing) secara tepat membuat karyawan menjadi betah bekerja. Di 
lingkungan kerja di mana ia ditempatkan akan membuat suasana hati yang membuat suasana kerja menjadi kondusif dan nyaman untuk berkomunikasi antar karyawan di satu bagian tersebut. Seringkali adanya komunikasi yang terjalin, saling mendukung satu sama lainnya, merasa saling memerlukan dan memiliki tujuan yang sama atas target yang diinginkan oleh perusahaan. Hal ini sejalan seperti yang dikemukakan oleh Sedarmayati (2009:75) yang berpendapat bahwa, lingkungan kerja yang baik akan mendorong supaya pegawai senang bekerja dan meningkatkan rasa tanggung jawab untuk melakukan pekerjaan dengan baik. Berdasarkan penelitian sebelumnya dan menurut ahli, dapat dianalogikakan bahwa staffing (pengaturan staf) mendukung proses menuju kinerja yang baik.

Penelitian Pengaruh Pengembangan Karir terhadap Kinerja Karyawan (Studi Kasus di PT.Telkom Malang) yang dilakukan oleh Ita Rifiani Permatasari (2018), memberikan gambaran bahwa penting pengembangan karir untuk memacu karyawan terus giat bekerja sehingga menghasilkan kinerja yang baik. Hal ini didukung oleh Robbins (1996) di mana ia menyatakan bahwa pengembangan karir merupakan suatu cara bagi organisasi untuk mendukung atau meningkatkan produktivitas para karyawan, sekaligus mempersiapkan mereka untuk menghadapi dunia yang berubah.

Dapat disimpulkan bahwa dengan adanya rekrutmen, pengaturan staf dan pengembangan karir menjadi bagian pemicu kenapa suatu perusahaan atau organisasi dapat terus bertahan dan berkembang dari masa ke masa. Hal ini dikarenakan dengan adanya ketiga faktor tersebut menjadikan perusahaan atau organisasi juga turut serta memacu karyawan untuk menjadi pribadi yang lebih baik, dapat diandalkan dan sesuai dengan keinginan perusahaan atau organisasi.

Atas teori dan fakta lapangan yang sudah terjadi, dikira sangat penting untuk diteliti kembali dari faktor rekrutmen, pengaturan staf (staffing) dan pengembangan karir agar lebih relevan dengan kenyataan di lapangan sekarang, tentu dengan waktu dan sampel yang berbeda. Hal ini juga turut menguji teori terdahulu yang menyatakan bahwa rekrutmen, pengaturan staf (staffing) dan pengembangan karir menempati bagian penting dalam suatu organisasi atau perusahaan pengaruh terhadap kinerja. Dalam hal ini, pengukuran kinerja karyawan sangatlah penting untuk diuji karena sebuah perusahaan atau organisasi yang hebat tentu memiliki sumber daya manusia yang juga hebat, mampu bersaing, dan dapat diandalkan. Oleh karena itu, penelitian rekrutmen, pengaturan staf (staffing) dan pengembangan karir atas kinerja karyawan dikira sangatlah penting khususnya untuk pengembangan di wilayah Kalimantan pada umumnya dan Banjarmasin pada khususnya. Terlebih peneliti yang merupakan bagian dari Sekolah Tinggi Ilmu Manajemen Indonesia (STIMI) Banjarmasin mengangkat penelitian ini sebagai bagian dari penilaian secara ilmiah, mengingat selama ini belum ada data tertulis mengenai kinerja atas karyawan yang selama ini sudah bekerja, belum lagi tugas dan fungsi dari suatu lembaga pendidikan seperti STIMI Banjarmasin untuk dapat terus berkembang dan menyesuaikan dengan dunia pendidikan yang sekarang diharapkan lulusanya dapat bersaing di dunia pekerjaan, akan menjadi lebih diperhatikan lagi yaitu usia lembaga pendidikan tersebut yang tidak lagi muda sehingga sangat perlu diukur secara terus menerus dilakukan penilaian kinerja karyawannya

Melalui uraian tersebut di atas, dapat ditampilkan permasalahan pada penelitian ini adalah sebagai berikut: Bagaimana deskripsi variabel rekrutmen, pengaturan staf dan pengembangan karier terhadap kinerja karyawan Sekolah Tinggi Ilmu Manajemen Indonesia (STIMI) Banjarmasin, pengaruhnya bagaimana dan yang berpengaruh dominan signifikan.

\section{I.2. Rumusan Masalah}

Berdasarkan latar belakang di atas, maka dapat diambil rumusan masalah sebagai berikut:

1. Bagaimana deskripsi variabel rekrutmen, pengaturan staf dan pengembangan karier terhadap kinerja karyawan Sekolah Tinggi Ilmu Manajemen Indonesia (STIMI) Banjarmasin?

2. Bagaimana pengaruh variabel rekrutmen, pengaturan staf dan pengembangan karier terhadap kinerja karyawan Sekolah Tinggi Ilmu Manajemen Indonesia (STIMI) Banjarmasin?

3. Manakah dari variabel rekrutmen, pengaturan staf dan pengembangan karier yang berpengaruh dominan signifikan terhadap kinerja karyawan Sekolah Tinggi Ilmu Manajemen Indonesia (STIMI) Banjarmasin?

\section{KAJIAN LITERATUR}


Kinerja dalam suatu organisasi adalah jawaban dari berhasil atau tidaknya tujuan organisasi yang telah ditetapkan. Para atasan atau manajer sering kali tidak memperhatikan kinerja kecuali sudah sangat buruk atau segala sesuatu jadi tidak bagus. Terlalu sering manajer tidak mengetahui betapa buruknya kinerja telah merosot sehingga perusahaan atau instansi menghadapi krisis yang serius. Adanya kesan-kesan buruk organisasi yang mendalam berakibat dan mengabaikan tanda-tanda peringatan atas adanya kinerja yang merosot.

Mangkunegara (2000:67), mendefinisikan "Kinerja (prestasi kerja) adalah hasil kerja secara kualitas dan kuantitas yang dicapai oleh seseorang pegawai atau karyawan dalam melaksanakan tugasnya sesuai dengan tanggung jawab yang diberikan kepadanya".

Selanjutnya Ambar Teguh Sulistiyani (2003:223), menjelaskan bahwa "Kinerja seseorang adalah kombinasi dari kemampuan, usaha dan kesempatan yang dapat dinilai dari hasil kerjanya". Adapun menurut Hasibuan (2001:34) mengemukakan "kinerja (prestasi kerja) adalah suatu hasil kerja yang dicapai seseorang dalam melaksanakan tugas tugas yang dibebankan kepadanya yang didasarkan atas kecakapan, pengalaman dan kesungguhan serta waktu".

Ada juga yang dikemukakan oleh Whitmore (1997:104), bahwa kinerja adalah pelaksanaan fungsi-fungsi yang dituntut dari seseorang, kinerja adalah suatu perbuatan, suatu prestasi, suatu pameran umum ketrampilan. Cushway (2002:1998), di mana kinerja adalah menilai bagaimana seseorang telah bekerja dibandingkan dengan target yang telah ditentukan.

Ada pula yang dijelaskan oleh Rivai (2004:309) mengemukakan kinerja adalah merupakan perilaku yang nyata ditampilkan setiap orang sebagai hasil kerja yang dihasilkan oleh karyawan sesuai dengan perannya dalam perusahaan atau organisasi. Yang lainnya oleh Robert L. Mathis dan John H. Jackson, yang diterjemahkan oleh Sadeli \& Prawira (2001:78), secara ringkas bahwa kinerja pada dasarnya adalah apa yang dilakukan atau tidak dilakukan karyawan.

Mink (1993:76) berpendapat bahwa individu yang memiliki kinerja yang bagus atau tinggi memiliki karakteristik, yaitu diantaranya: (a) berorientasi prestasi, (b) percaya diri, (c) pengendalian diri, (d) berkompetensi.

Rekrutmen (Penarikan) adalah proses mendapatkan sejumlah calon tenaga kerja yang kualifaid untuk jabatan/pekerjaan utama (produk lini dan penunjangnya) di lingkungan suatu organisasi/perusahaan (Nawawi:2005).

Terdapat tiga kegiatan pokok yang terdiri dari:

a. Kegiatan Seleksi

b. Kegiatan Penempatan

c. Kegiatan Sosialisasi/Orientasi

Selanjutnya rekrutmen adalah suatu keputusan perencanaan di bidang manajemen sumber daya manusia mengenai jumlah karyawan yang diperlukan, kapan disediakan, serta kriteria apa saja yang harus dipenuhi dalam suatu organisasi.

Rekrutmen hakikatnya merupakan usaha untuk mengisi jabatan atau pekerjaan yang sedang atau akan kosong pada masa yang akan datang di lingkungan suatu organisasi atau perusahaan, sehingga terdapat dua sumber tenaga kerja yakni sumber dari luar (eksternal) organisasi atau dari dalam (internal) organisasi. Penarikan (rekrutmen) pegawai merupakan suatu proses atau tindakan yang dilakukan oleh organisasi untuk mendapatkan tambahan pegawai melalui beberapa tahapan yang mencakup identifikasi dan evaluasi sumber-sumber penarikan tenaga kerja, menentukan kebutuhan tenaga kerja, proses seleksi, penempatan, dan orientasi tenaga kerja. Penarikan pegawai bertujuan menyediakan pegawai yang cukup agar manajer dapat memilih karyawan yang memenuhi kualifikasi yang mereka perlukan (Malthis:2001). Rekrutmen yang efektif memerlukan tersedianya informasi yang akurat dan berkesinambungan mengenai jumlah dan kualifikasi individu yang diperlukan untuk melaksanakan berbagai pekerjaan dalam organisasi.

Proses Rekrutmen

Handoko (2008) menjelaskan bahwa proses rekrutmen (penarikan) secara ringkas dapat dijelaskan pada gambar berikut :

Gambar 2.2. Proses Rekrutmen 


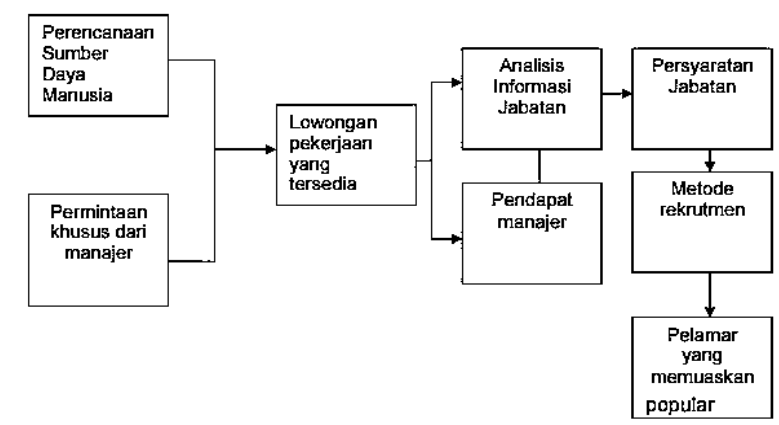

Sumber : Handoko (2008)

Proses rekrutmen saat ini memiliki beberapa istilah JobSpecification, JobEvaluation, JobClassification, dan lain sebagainya. Dapat diuraikan sebagai berikut :

a. JobAnalysis (Analisis Jabatan) merupakan prosedur untuk menentukan tanggung jawab dan persyaratan, ketrampilan dari sebuah pekerjaan dan jenis orang yang akan dipekerjakan.

b. JobDescription (Uraian Jabatan), Yoder (dalam Moekijat, 2010) mengatakan bahwa uraian jabatan adalah mengihktisarkan fakta-fakta yang diberikan oleh analisis jabatan dalam susunan yang sistematis. Uraian jabatan merupakan garis-garis besar yang ditulis dan dimaksudkan untuk memberikan keterangan tentang fakta-fakta yang penting dari jabatan yang diperlukan.

c. JobSpecification (Persyaratan Jabatan) adalah catatan mengenai syarat-syarat minimum harus dimiliki untuk menyelesaikan suatu pekerjaan dengan baik (Moekijat :2010)

d. JobEvaluation (Penilaian Jabatan), Moekijat (2010) mengemukakan bahwa penilaian jabatan adalah kegiatan yang dilakukan guna membandingkan nilai dari suatu jabatan dengan nilai dari jabatan dengan jabatan lainnya.

e. JobClassification (Penggolongan jabatan) adalah pengelompokan jabatan-jabatan yang memiliki nilai yang sama (Moekijat,2010).

\section{Penentuan Dasar Rekrutmen}

Hasibuan (2008) berpendapat bahwa dasar penarikan calon karyawan harus ditetapkan lebih dahulu supaya para pelamar yang akan memasukkan lamarannya sesuai dengan pekerjaan atau jabatan yang diminatinya. Dasar penarikan harus berpedoman pada spesifikasi pekerjaan yang telah ditentukan untuk menduduki jabatan tersebut. JobSpecification harus diuraikan secara terperinci dan jelas agar para pelamar mengetahui kualifikasi yang dituntut oleh lowongan kerja tersebut. Jika spesifikasi pekerjaan dijadikan dasar dan pedoman penarikan, maka karyawan yang diterima akan sesuai dengan uraian pekerjaan dari jabatan yang diperlukan oleh perusahaan.

\section{Staffing (Pengaturan Staf)}

Pengaturan staf adalah lanjutan dari kegiatan rekrutmen (penarikan) berupa pengambilan keputusan dalam menerima dan menempatkan tenaga kerja. Oleh karena itu kegiatan pengaturan staf sering disebut juga sebagai kegiatan seleksi tenaga kerja.

R. Duane dan J. Clifton (1989:239) menjelaskan bahwa staffing (pengaturan staf) merupakan proses formal dari memastikan bahwa organisasi yang mempunyai sumber daya bertanda ijazah atau memenuhi persyaratan untuk mendekati tujuan yang ingin dicapai, dan mewakili sumber asal kehidupan dari setiap perusahaan.

Selain itu, menurut Jhon (1984) mengartikan staffing sebagai suatu proses untuk pengisian suatu posisi pekerjaan dengan orang yang tepat atau sesuai. Ini sebagai bagian dari tugas seorang manajer organisasi. Dan hal tersebut pada dasarnya sebagai suatu seni dari penempatan orang-orang yang memiliki ijazah atau memenuhi syarat dan memiliki minat atau ketertarikan atas posisi jabatan pekerjaan yang ditawarkan oleh perusahaan. 
Sedikit berbeda dengan T. Hani Handoko (2003:233), menjelaskan bahwa penyusunan personalia (staffing) adalah suatu fungsi manajemen yang membahas penarikan, penempatan, pemberian latihan, dan pengembangan anggota-anggota organisasi.

\section{Pengembangan Karier}

Pengembangan merupakan fungsi operasional yang bertujuan untuk meningkatkan keterampilan pegawai. Tingkat keterampilan ini dapat dicapai melalui pendidikan dan pelatihan yang diberikan perusahaan untuk karyawan, baik yang baru masuk ataupun yang sudah lama bekerja di perusahaan tersebut.

Pengembangan adalah peningkatan pribadi yang dilakukan seseorang untuk mencapai suatu rencana karir dan peningkatan oleh departemen personalia untuk mencapai suatu rencana kerja sesuai dengan jalur atau jenjang organisasi.

Karir adalah keseluruhan jabatan atau pekerjaan atau posisi yang dapat diduduki seseorang selama kehidupan kerjanya dalam organisasi atau dalam beberapa organisasi. Dari sudut pandang pegawai atau karyawan, jabatan merupakan suatu hal yang sangat penting sebab setiap orang menginginkan suatu jabatan yang sesuai dengan keinginannya dan menginginkan jabatan setinggi mungkin sesuai dengan kemampuannya.

Menurut I Komang A. Dkk. (2012) pengembangankarir adalah peningkatan pribadi yang dilakukan seseorang untuk mencapai suatu rencana karir dan peningkatan oleh departemen personalia untuk mencapai suatu rencana kerja sesuai dengan jalur atau jenjang organisasi.

Bentuk-Bentuk Pengembangan Karir

\section{METODE PENELITIAN}

Penelitian ini menggunakan pendekatan eksplanatif dengan teknik survei untuk menjelaskan hubungan kausalitas antara variabel pengaruh rekrutmen, pengaturan staf dan pengembangan karier terhadap kinerja karyawan Sekolah Tinggi Ilmu Manajemen Indonesia (STIMI) Banjarmasin. Dalam penelitian ini, variabel-variabel yang diteliti tidak dikendalikan.

Populasi dalam penelitian ini adalah seluruh karyawan Sekolah Tinggi Ilmu Manajemen Indonesia (STIMI) Banjarmasin, dengan kriteria sebagai berikut.

1. Karyawan yang berstatus pegawai tetap.

2. Karyawan yang telah bekerja selama lebih dari 3 tahun.

3. Karyawan yang telah berusia 22-58 tahun.

4. Karyawan terbagi atas dosen dan tenaga kependidikan.

Pengambilan sampling menggunakan total sampling atau pengambilan sampel secara keseluruhan, hal ini dilakukan karena total sampel hanya berjumlah 30 orang.

Jenis dan Sumber Data

Penelitian ini menggunakan data subjek, yaitu berupa respon tertulis dari responden berkaitan dengan butir-butir pertanyaan atau pernyataan ayng dikolaborasikan dari masing-masing indikator pada setiap variabel. Oleh karena itu, sumber data penelitian ini adalah sumber data primer. Untuk mengurangi dan menghlndarkan data bisa, dilakukan wawancara langsung dengan responden.

Instrumen Penelitian

Instrumen penelitian ini adalah kuesioner yang disusun secara berurutan menurut indikator-indikator variabel penelitian, disajikan pada lampiran. Untuk menjamin validitas dan reliabilotasnya, uji validitas dan uji reliabilitas instrumen dilakukan dengan cara pada bagian E dan F.

Pengumpulan data dilakukan dengan cara ditujukan langsung kepada responden yang ada. Uji Asumsi Klasik

Regresi linear berganda harus memenuhi asumsi-asumsi yang diterapkan agar menghasilkan nilai-nilai koefisien sebagai penduga yang tidak bisa. Apabila asumsi tersebut tidak terpenuhi maka akan muncul gejala berikut.

a. Gejala heteroskedastisitas

Gejala heteroskedastisitas diuji dengan Metode Glesjer dengan cara menyusun regresi antara nilai absolut residual dengan variabel bebas. Jika masing-masing variabel bebas tidak berpengaruh signifikan terhadap absolut residual $(\alpha=0,05)$ maka dalam model regresi tidak terjadi gejala heteroskedastisitas. 
b. Gejala autokorelasi

Untuk mendeteksi gejala autokorelasi dilakukan dengan pengujian Durbin Watson (d). Hasil perhitungan Durbin Watson (d) dibandingkan dengan nilai d table pada $\alpha=0,05$. Tabel $\mathrm{d}$ memiliki dua nilai, yaitu nilai batas atas $\left(\mathrm{d}_{\mathrm{U}}\right)$ dan nilai batas bawah $\left(\mathrm{d}_{\mathrm{L}}\right)$ untuk berbagai nilai $\mathrm{n}$ dan $\mathrm{k}$.

Jika $\quad \mathrm{d}<\mathrm{d}_{\mathrm{L}}$; terjadi autokorelasi positif; $\mathrm{d}>4-\mathrm{d}_{\mathrm{L}}$; terjadi autokorelasi negatif; $\mathrm{d}_{\mathrm{U}}<\mathrm{d}<4-\mathrm{d}_{\mathrm{U}}$; tidak terjadi autokorelasi; $\mathrm{d}_{\mathrm{L}} \leq \mathrm{d} \leq \mathrm{d}_{\mathrm{U}}$ atau $4-\mathrm{d}_{\mathrm{U}} \leq \mathrm{d} \leq 4-\mathrm{d}_{\mathrm{L}}$; pengujian tidak meyakinkan.

c. Gejala multikolinearitas

Pendeteksian terhadap multikolinearitas dilakukan dengan melihat nilai Variance-Inflating Factor (VIF) dari hasil analisis regresi. Jika nilai VIF $>10$, terdapat gejala multikolinearitas.

Uji model dilakukan dengan menggunakan nilai $F$, namum sebelumnya dilakukan perhitungan koefisien determinasi $\left(\mathrm{R}^{2}\right)$ untuk mengetahui seberapa besar konstribusi variabel variabel rekrutmen, pengaturan staf dan pengembangan karier terhadap kinerja. Nilai $\mathrm{R}^{2}$ yang digunakan adalah nilai $\mathrm{R}^{2}$ adjusted yang dihitung dengan rumus:

$\mathrm{n}=$ sampel;

$$
\mathrm{R}_{\text {adjusted }=}^{2} \quad 1-\left(1-\mathrm{R}^{2}\right) \frac{\mathrm{n}-1}{\mathrm{n}-\mathrm{k}}
$$

$\mathrm{k}=$ banyak variabel bebas

$\mathrm{R}^{2}=$ koefisien determinasi dihitung dengan rumus:

$\mathrm{R}^{2}=\frac{\mathrm{SSR}}{\mathrm{SSE}}$

$\mathrm{SSR}=$ rata-rata kuadrat regresi

$\mathrm{SSE}=$ rata-rata kuadror

Selanjutnya, dilakukan uji model dengan menentukan besarnya $F$ hitung dengan rumus:

$$
F_{\text {hitung }}=\frac{\mathrm{SSR} / \mathrm{k}}{\mathrm{SST} /[\mathrm{n}-(\mathrm{k}+1)]}
$$

Hipotesis statistic dinyatakan dengan

$$
\begin{aligned}
\mathrm{H}_{0}: & \mathrm{b}_{1}=\mathrm{b}_{2}=\mathrm{b}_{3}=0 \text { [proporsi variasi } \\
& \text { dalam variabel tergantung (Y) } \\
& \text { yang dijelaskan secara bersama- } \\
& \text { sama oleh variabel bebas tidak } \\
& \text { signifikan] } \\
\mathrm{H}_{1}: & \text { Minimal satu koefisien dari } \mathrm{b}_{1} \neq \\
& 0 \text { [proporsi variasi dalam } \\
& \text { variabel tergantung (Y) yang } \\
& \text { dijelaskan secara bersama-sama } \\
& \text { oleh variabel bebas signifikan] }
\end{aligned}
$$

Jika $F_{\text {hitung }} \leq F_{\text {tabel }}[5 \% ; \mathrm{df}=\mathrm{k} ; \mathrm{n}-(\mathrm{k}+1)]$ maka $\mathrm{H}_{0}$ diterima. Sedangkan jika $F_{\text {hitung }}>F_{\text {tabel }}[5 \% ; \mathrm{df}=$ $\mathrm{k} ; \mathrm{n}-(\mathrm{k}+1)]$ maka $\mathrm{H}_{0}$ diterima

Uji signifikansi terhadap masing-masing koefisien regresi diperlukan untuk mengetahui signifikan tidaknya pengaruh dari masing-masing variabel rekrutmen, pengaturan staf dan pengembangan karier terhadap kinerja. Untuk itu, digunakan uji $t$ terhadap koefisien regresi parsial yang dihitung dengan rumus:

$$
t=\frac{\mathrm{b}_{1}}{\mathrm{~S}_{\mathrm{bi}}}
$$

$\mathrm{b}_{1=}$ koefisien regresi ke-i $(\mathrm{i}=1,2,3,4,5,6)$

$\mathrm{S}_{\mathrm{bi}}=\mathrm{standar}_{\mathrm{i}}$ deviasi dari koefisienb 1

hipotesis statistic dinyatakan dengan

$\mathrm{H}_{0}: \mathrm{b}_{\mathrm{i}}=0$ 
$\mathrm{H}_{0}: \mathrm{b}_{\mathrm{i}} \neq 0$

Jika $\mathrm{t}_{\text {tabel }} \leq \mathrm{t}_{\text {hitung }} \leq \mathrm{t}_{\text {tabel }}[0,05 / 2 ; \mathrm{df}=\mathrm{n}-(\mathrm{k}+1)]$ maka $\mathrm{H}_{0}$ diterima

sedangkant $\mathrm{t}_{\text {hitung }}<\mathrm{t}_{\text {tabel atau }} \mathrm{t}_{\text {hitung }}>\mathrm{t}_{\text {tabel }}[0,05 / 2 ; \mathrm{df}=\mathrm{n}-(\mathrm{k}+1)]$ maka $\mathrm{H}_{0}$ ditolak

Pengujian Instrumen

Uji validitas dilakukan dengan cara mengkorelasikan skor masing-masing butir pertanyaan pada tiap-tiap variabel dengan skor totalnya. Rumus yang digunakan adalah korelasi product moment, yaitu sebagai berikut:

\section{RUMUS PERSON PRÓDUCTS MOMENT}

$$
r=\frac{n\left(\sum X Y\right)-\left(\sum X\right)\left(\sum Y\right)}{\sqrt{\left[n \sum X^{2}-\left(\sum X\right)^{2}\right]\left[n \sum \bar{Y}^{2}-\left(\sum Y\right)^{2}\right]}}
$$

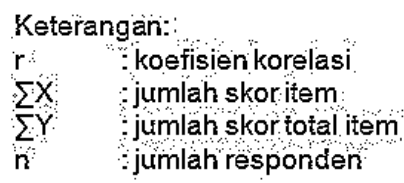

Kuesioner dinyatakan valid apabila nilai koefisien korelasi lebih besar dari pada nilai korelasi yang tercantum dalam table pada $\alpha=5 \%$.

Pengujian reliabilitas dilakukan dengan cara belah dua, yaitu membelah kuesioner menjadi dua bagian. Bagian pertama bernomor ganjil dan bagian kedua bernomor genap. Selanjutnya, skor total dari masing-masing belahan itu dikorelasikan dengan menggunakan rumus product moment sebagaimana menghitung validitas. Koefisien korelasi yang diperoleh tersebut dimasukkan ke dalam rumus Spearman-Brown, yaitu sebagai berikut.

$\mathrm{r}_{\mathrm{sb}}=$ reliabilitas

$$
r_{\mathrm{sb}}=\frac{2 r_{\mathrm{pm}}}{1+\mathrm{r}_{\mathrm{pm}}}
$$

$\mathrm{r}_{\mathrm{pm}}=$ koefisien korelasi product moment

Kuesioner dinyatakan reliable apabila nilai $\mathrm{r}_{\mathrm{sb}}$ hasil perhitungan lebih besar dari pada nilai $\mathrm{r}$ dalam table $\alpha=5 \%$.

Dalam penelitian ini, digunakan model regresi linear berganda yang dirumuskan sebagai berikut.

$\mathrm{Y}=\mathrm{a}+\mathrm{b}_{1} \mathrm{X}_{1}+\mathrm{b}_{2} \mathrm{X}_{2}+\mathrm{b}_{3} \mathrm{X}_{3}+\mathrm{e}$

Keterangan :

$\mathrm{Y}=$ kinerja

$\mathrm{X}_{1}=$ rekrutmen

$\mathrm{X}_{2}=$ pengaturan staf

$\mathrm{X}_{3}=$ pengembangan karier

$\mathrm{b}_{1,} \mathrm{~b}_{2}, \mathrm{~b}_{3}=$ koefisien regresi

$\mathrm{e} \quad=$ variabel pengganggu

Regresi linear berganda harus memenuhi asumsi-asumsi yang diterapkan agar menghasilkan nilai-nilai koefisien sebagai penduga yang tidak bisa. Apabila asumsi tersebut tidak terpenuhi maka akan muncul gejala berikut.

Pertama yaitu Gejala heteroskedastisitas yang diuji dengan Metode Glesjer dengan cara menyusun regresi antara nilai absolut residual dengan variabel bebas. Jika masing-masing variabel bebas tidak berpengaruh signifikan terhadap absolut residual $(\alpha=0,05)$ maka dalam model regresi tidak terjadi gejala heteroskedastisitas. 
Kedua, mendeteksi gejala autokorelasi dilakukan dengan pengujian Durbin Watson (d). Hasil perhitungan Durbin Watson (d) dibandingkan dengan nilai d table pada $\alpha=0,05$. Tabel $\mathrm{d}$ memiliki dua nilai, yaitu nilai batas atas $\left(\mathrm{d}_{\mathrm{U}}\right)$ dan nilai batas bawah $\left(\mathrm{d}_{\mathrm{L}}\right)$ untuk berbagai nilai $\mathrm{n}$ dan $\mathrm{k}$.

Jika $\mathrm{d}<\mathrm{d}_{\mathrm{L}}$; terjadi autokorelasi positif; $\mathrm{d}>4-\mathrm{d}_{\mathrm{L}}$; terjadi autokorelasi negatif; $\mathrm{d}_{\mathrm{U}}<\mathrm{d}<4-\mathrm{d}_{\mathrm{U}}$; tidak terjadi autokorelasi; $\mathrm{d}_{\mathrm{L}} \leq \mathrm{d} \leq \mathrm{d}_{\mathrm{U}}$ atau $4-\mathrm{d}_{\mathrm{U}} \leq \mathrm{d} \leq 4-\mathrm{d}_{\mathrm{L}}$; pengujian tidak meyakinkan.

Ketiga, pendeteksian terhadap multikolinearitas dilakukan dengan melihat nilai VarianceInflating Factor (VIF) dari hasil analisis regresi. Jika nilai VIF $>10$, terdapat gejala multikolinearitas.

Keempat, uji model dilakukan dengan menggunakan nilai $F$, namum sebelumnya dilakukan perhitungan koefisien determinasi $\left(\mathrm{R}^{2}\right)$ untuk mengetahui seberapa besar konstribusi variabel variabel rekrutmen, pengaturan staf dan pengembangan karier terhadap kinerja. Nilai $\mathrm{R}^{2}$ yang digunakan adalah nilai $\mathrm{R}_{\text {adjusted yang dihitung dengan rumus: }}^{2}$

$\mathrm{n}=$ sampel;

$$
\mathrm{R}^{2} \text { adjusted }=1-\left(1-\mathrm{R}^{2}\right) \frac{\mathrm{n}-1}{\mathrm{n}-\mathrm{k}}
$$

$\mathrm{k}=$ banyak variabel bebas

$\mathrm{R}^{2}=$ koefisien determinasi dihitung dengan rumus:

$\mathrm{R}^{2}=\frac{\mathrm{SSR}}{\mathrm{SSE}}$

$\mathrm{SSR}=$ rata-rata kuadrat regresi

$\mathrm{SSE}=$ rata-rata kuadror

Selanjutnya, dilakukan uji model dengan menentukan besarnya $F$ hitung dengan rumus:

$$
F_{\text {hitung }}=\frac{\mathrm{SSR} / \mathrm{k}}{\mathrm{SST} /[\mathrm{n}-(\mathrm{k}+1)]}
$$

Hipotesis statistic dinyatakan dengan

$\mathrm{H}_{0}: \quad \mathrm{b}_{1}=\mathrm{b}_{2}=\mathrm{b}_{3}=0$ [proporsi variasi dalam variabel tergantung (Y) yang dijelaskan secara bersama-sama oleh variabel bebas tidak signifikan]

$\mathrm{H}_{1}$ : Minimal satu koefisien dari $\mathrm{b}_{1} \neq 0$ [proporso variasi dalam variabel tergantung (Y) yang dijelaskan secara bersama-sama oleh variabel bebas signifikan]

Jika $F_{\text {hitung }} \leq F_{\text {tabel }}[5 \% ; \mathrm{df}=\mathrm{k} ; \mathrm{n}-(\mathrm{k}+1)]$ maka $\mathrm{H}_{0}$ diterima. Sedangkan jika $F_{\text {hitung }}>F_{\text {tabel }}[5 \% ; \mathrm{df}=$ $\mathrm{k} ; \mathrm{n}-(\mathrm{k}+1)]$ maka $\mathrm{H}_{0}$ diterima

Pengujian Hipotesis

Uji signifikansi terhadap masing-masing koefisien regresi diperlukan untuk mengetahui signifikan tidaknya pengaruh dari masing-masing variabel rekrutmen, pengaturan staf dan pengembangan karier terhadap kinerja. Untuk itu, digunakan uji $t$ terhadap koefisien regresi parsial yang dihitung dengan rumus:

$$
t=\frac{\mathrm{b}_{1}}{\mathrm{~S} \mathrm{bi}}
$$

$\mathrm{b}_{1}=$ koefisien regresi ke-i $(\mathrm{i}=1,2,3,4,5,6)$

$\mathrm{s}_{\mathrm{bi}}=\mathrm{standar}_{\mathrm{s}}$ deviasi dari koefisien $\mathrm{b}_{1}$

hipotesis statistic dinyatakan dengan

$\mathrm{H}_{0}: \mathrm{b}_{\mathrm{i}}=0$

$\mathrm{H}_{0}: \mathrm{b}_{\mathrm{i}} \neq 0$

Jika $\mathrm{t}_{\text {tabel }} \leq \mathrm{t}_{\text {hitung }} \leq \mathrm{t}_{\text {tabel }}[0,05 / 2 ; \mathrm{df}=\mathrm{n}-(\mathrm{k}+1)]$ maka $\mathrm{H}_{0}$ diterima

sedangkant ${ }_{\text {hitung }}<\mathrm{t}_{\text {tabel atau }} \mathrm{t}_{\text {hitung }}>\mathrm{t}_{\text {tabel }}[0,05 / 2 ; \mathrm{df}=\mathrm{n}-(\mathrm{k}+1)] \mathrm{maka}_{0}$ ditolak

\section{HASIL PENELITIAN DAN PEMBAHASAN}

Pengukuran validitas dengan menggunakan korelasi productmomentdengan tingkat kepercayaan $95 \%(\alpha=5 \%)$, dengan cara mengkorelasikan skor masing-masing item dengaan skor totalnya. Hasil pengujian penelitian ini dapat dilihat pada tabel berikut: 
Tabel 4.1 Hasil Uji Validitas Instrumen Penelitian

\begin{tabular}{|c|c|c|c|c|c|}
\hline No & Variabel & Item & $\begin{array}{l}\text { Koefisien } \\
\text { Korelasi }\end{array}$ & $\begin{array}{l}\text { Sig. } \\
(2- \\
\text { tailed })\end{array}$ & Hasil \\
\hline \multirow{7}{*}{1} & \multirow{7}{*}{$\begin{array}{l}\text { Proses } \\
\text { Rekrutmen } \\
\left(\mathrm{X}_{1}\right)\end{array}$} & $\mathrm{X}_{11}$ & 0,711 & 0,000 & Valid \\
\hline & & $\mathrm{X}_{12}$ & 0,500 & 0,500 & Valid \\
\hline & & $\mathrm{X}_{13}$ & 0,611 & 0,000 & Valid \\
\hline & & $\mathrm{X}_{14}$ & 0,579 & 0,001 & Valid \\
\hline & & $X_{15}$ & 0,692 & 0,000 & Valid \\
\hline & & $\mathrm{X}_{16}$ & 0,648 & 0,000 & Valid \\
\hline & & $X_{17}$ & 0,477 & 0,008 & Valid \\
\hline \multirow{14}{*}{2} & \multirow{14}{*}{$\begin{array}{l}\text { Pengaturan } \\
\operatorname{staf}\left(X_{2}\right)\end{array}$} & $\mathrm{X}_{21}$ & 0,432 & 0,017 & Valid \\
\hline & & $X_{22}$ & 0,436 & 0,016 & Valid \\
\hline & & $X_{23}$ & 0,587 & 0,001 & Valid \\
\hline & & $\mathrm{X}_{24}$ & 0,543 & 0,002 & Valid \\
\hline & & $X_{25}$ & 0,630 & 0,000 & Valid \\
\hline & & $X_{26}$ & 0,712 & 0,000 & Valid \\
\hline & & $\mathrm{X}_{27}$ & 0,553 & 0,002 & Valid \\
\hline & & $\mathrm{X}_{28}$ & 0,663 & 0,000 & Valid \\
\hline & & $\mathrm{X}_{29}$ & 0,365 & 0,047 & Valid \\
\hline & & $\mathrm{X}_{210}$ & 0,715 & 0,000 & Valid \\
\hline & & $\mathrm{X}_{211}$ & 0,271 & 0,147 & Valid \\
\hline & & $\mathrm{X}_{212}$ & 0,445 & 0,014 & Valid \\
\hline & & $\mathrm{X}_{213}$ & 0,571 & 0,001 & Valid \\
\hline & & $\mathrm{X}_{214}$ & 0,488 & 0,006 & Valid \\
\hline \multirow{5}{*}{3} & \multirow{5}{*}{$\begin{array}{l}\text { Pengembangan } \\
\text { Karier }\left(\mathrm{X}_{3}\right)\end{array}$} & $X_{31}$ & 0,631 & 0,000 & Valid \\
\hline & & $X_{32}$ & 0,559 & 0,001 & Valid \\
\hline & & $\mathrm{X}_{33}$ & 0,589 & 0,001 & Valid \\
\hline & & $\mathrm{X}_{34}$ & 0,662 & 0,000 & Valid \\
\hline & & $X_{35}$ & 0,717 & 0,000 & Valid \\
\hline \multirow{7}{*}{4} & \multirow{7}{*}{$\begin{array}{l}\text { Kinerja } \\
\text { Karyawan (Y) }\end{array}$} & $\mathrm{Y}_{1}$ & 0,619 & 0,000 & Valid \\
\hline & & $\mathrm{Y}_{2}$ & 0,781 & 0,000 & Valid \\
\hline & & $\mathrm{Y}_{3}$ & 0,630 & 0,000 & Valid \\
\hline & & $\mathrm{Y}_{4}$ & 0,742 & 0,000 & Valid \\
\hline & & $\mathrm{Y}_{5}$ & 0,712 & 0,000 & Valid \\
\hline & & $\mathrm{Y}_{6}$ & 0,605 & 0,000 & Valid \\
\hline & & $\mathrm{Y}_{7}$ & 0,724 & 0,000 & Valid \\
\hline
\end{tabular}

Sumber : Data Diolah

Instrumen dikatakan valid jika korelasi product moment menunjukkan korelasi yang signifikan antara skor item dengan skor total, di mana nilai signifikan $\alpha>0,05$ atau dengan cara membandingkan nilai korelasi masing-masing item dengan nilai korelasi tabel $\left(r_{\text {tabel }}\right)$, jika $r_{\text {product moment }}>r_{\text {tabel }}$ maka instrumen tersebut dikatakan valid. Apabila sudah diketahui bahwa instrumen yang ada semuanya telah valid, sehingga dilanjutkan untuk diuji reliaabilitasnya.

a. Uji Reliabilitas

Uji reliabilitas digunakan untuk menguji konsistensi alat ukur (instrumen) yang digunakan dalam penelitian, sehingga dapat diketahui apakah instrumen tersebut cukup akurat dan konsisten sebagai alat pengumpul data. Teknik pengukuran data menggunakan alphacronbach dengan tingkat kepercayaan $95 \%(\alpha=5 \%)$. 
Tabel 4.2 Hasil Uji Reliabilitas Instrumen Penelitian

\begin{tabular}{|l|l|l|l|}
\hline No & Variabel & $\begin{array}{l}\text { Nilai } \\
\text { Alpha }\end{array}$ & $\begin{array}{l}\text { Koefisien } \\
\text { Korelasi }\end{array}$ \\
\hline 1 & $\mathrm{X}_{1}$ & 0,704 & Reliabel \\
\hline 2 & $\mathrm{X}_{2}$ & 0,800 & Reliabel \\
\hline 3 & $\mathrm{X}_{3}$ & 0,624 & Reliabel \\
\hline 4 & $\mathrm{Y}$ & 0,814 & Reliabel \\
\hline
\end{tabular}

Hasil dari perhitungan reliabilitas disajikan pada lampiran analisa data di mana diperoleh koefisien reliabilitas atau alpha sebesar 0,704 untuk varibel $X_{1}, 0,800$ untuk varibel $X_{2}, 0,624$ untuk varibel $\mathrm{X}_{3}$, dan 0,814 untuk varibel $\mathrm{Y}$. Dengan demikian, semua nilai reliabilitas semuanya semakin mendekati 1 yang berarti semakin reliabel. Karena hasil pengujian menunjukkan nilai koefisien reliabilitas mendekati 1 maka seluruh item dinyatakan reliabel.

1. Uji Asumsi Klasik

a. Uji Multikolinearitas

Untuk menguji ada tidaknya gejala multikolinearitas pada model regresi linier berganda yang diajukan dengan melihat nilai variance inflating faktor (VIF), jika VIF $<10$ maka tidak terjadi multikolinearitas (Gujarati, 1995:339).

Tabel 4.3 Variance Inflating Faktor (VIF)

Coefficients $^{\mathrm{a}}$

\begin{tabular}{|ll|l|}
\hline \multirow{2}{*}{\multicolumn{1}{|c|}{}} & \multicolumn{1}{|l|}{$\begin{array}{l}\text { Collinearity } \\
\text { Statistics }\end{array}$} \\
\cline { 2 - 3 } & SIF \\
\hline $1 \quad$ (Constant) & \\
X1 & 1,501 \\
X2 & 1,935 \\
X3 & 1,725 \\
\hline
\end{tabular}

a. Dependent Variabel: Y

Dari tabel dapat diketahui bahwa keseluruhan nilai VIF variabel proses rekrutmen $\left(\mathrm{X}_{1}\right)$, pengaturan staf $\left(\mathrm{X}_{2}\right)$ dan pengembangan karir $\left(\mathrm{X}_{3}\right)$ berada di bawah nilai 10, dengan demikian tidak terjadi gejala multikolinearitas.

b. $\quad$ Auto Korelasi

Untuk mendeteksi terhadap gejala autokorelasi dapat dilakukan dengan pengujian Durbin Watson $(D W)$ statistic melalui tes DW. Apabila nilai Durbin Watson berada di antara nilai (4-d $\mathrm{d}_{\mathrm{u}}$ ) atau nilai DWtest $>D_{u}$ maka dapat dikatakan tidak terdapat gejala autokorelasi. Untuk lebih jelasnya daapt dilihat pada tabel Durbin Watson statistic yang mencantumkan batas bawah $\left(\mathrm{d}_{1}\right)$ dan batas atas $\left(\mathrm{d}_{\mathrm{u}}\right)$ untuk model regresi dengan jumlah sampel tertentu (n).

Hasil perhitungan Durbin Watson yang ada (lampiran ....) sebesar 1,839 dengan menggunakan tabel DW pada taraf nyata $5 \%$ dan jumlah variabel bebas sebanyak 3 , jumlah observasi sebanyak 30 responden, maka nilai du sebesar 1,8282 serta nilai d1 sebesar 1,6019

Dengan demikian nilai $\mathrm{d}<\mathrm{d}_{\mathrm{i}}$ maka dapat disimpulkan bahwa model regresi yang diajukan terjadi autokorelasi possitif.

c. Uji Heteroskedastisitas

Untuk menguji asumsi tentang ada tidaknya varians dari unsur gangguan (e), berhubungan dengan variabel-variabel bebas. Ada beberapa metode untuk mendeteksi situasi heteroskedasitas dalam variants error terms suatu regresi di antaranya Metode Spearman Rang Correlation yaitu dengan membandinhkan nilai Sig. (2-tailed) masing-masing variabel bebas dengan nilai signifikan ( $\alpha$ $=5 \%)$. Untuk lebih jelasnya dapat dilihat pada tabel 4.15 di bawah ini. 
Tabel 4.4 Korelasi

\begin{tabular}{|c|c|c|c|c|}
\hline & $Y$ & $\mathrm{X} 1$ & $\mathrm{X} 2$ & $\mathrm{X} 3$ \\
\hline Pearson Y & 1,000 & 365 & 033 &, 184 \\
\hline Correlati X1 &, 365 & 1,000 &, 556 &, 474 \\
\hline $\mathrm{X} 2$ & , 033 & ,556 & 1,000 &, 631 \\
\hline X3 & , 184 & , 474 & ,631 & 1,000 \\
\hline Sig. (1- Y & &, 024 &, 430 &, 165 \\
\hline tailed) $\quad \mathrm{X} 1$ & , 024 & & ,001 & ,004 \\
\hline $\mathrm{X} 2$ &, 430 &, 001 & - &, 000 \\
\hline X3 &, 165 &, 004 &, 000 & \\
\hline $\mathrm{N}$ & 30 & 30 & 30 & 30 \\
\hline X1 & 30 & 30 & 30 & 30 \\
\hline $\mathrm{X} 2$ & 30 & 30 & 30 & 30 \\
\hline X3 & 30 & 30 & 30 & 30 \\
\hline
\end{tabular}

Dari tabel tersebut daapt disimpulkankan bahwa semua variabel yang ada, semuanya tidak terjadi heteroskedastisitas karena nilai Sig. (1-tailed) masing-masing variabel bebas nilainya lebih besar dari 0,05 atau $5 \%$.

d. Uji Normalitas

Bertujuan untuk menguji apakah dalam model regresi, variabel terikat dan bebas keduanya mempunyai distribusi normal atau tidak. Pengujian ini dilakukan dengan analisis grafik.

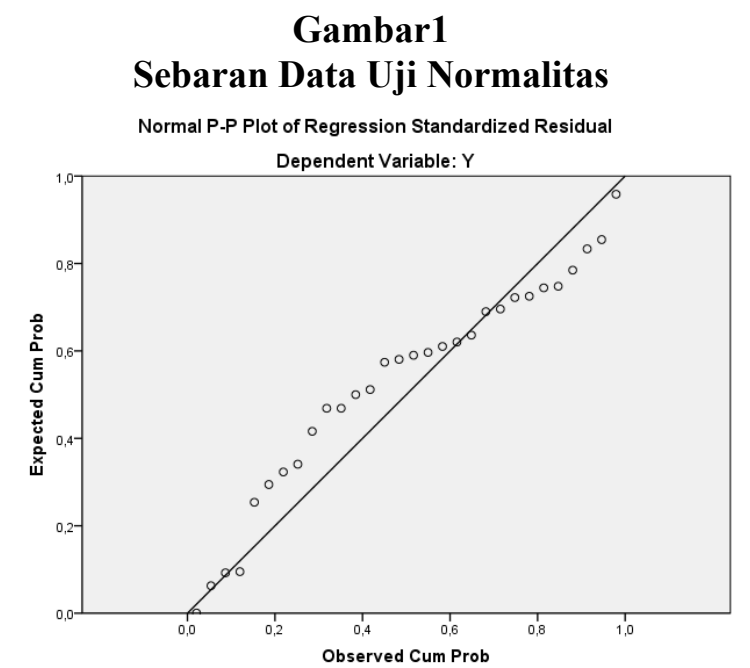

Pada gambar di atas tampak bahwa sebaran data menyebar di sekitar garis diagonal, dengan demikian data penelitian yang diperoleh dapat dinyatakan normal.

2. Pengujian Hipotesis

Dalam penelitian ini, sampel yang digunakan sebanyak 30 orang pegawai atau karyawan yang berada di Sekolah Tinggi Ilmu Manajemen Indonesia (STIMI) Banjarmasin. Persamaan regresi yang menghubungkan beberapa predictor dengan satu kriterium dengan alasan untuk apa yang dikemukan pada hipotesa yang diajukan.

Sebagaimana yang telah ditulis pada bab sebelumnya, penelitian ini akan dibantu dengan program SPSS for windows (lampiran). Model Regresi yang digunakan sebagai berikut:

$$
\mathrm{Y}=\mathrm{a}+\mathrm{b}_{1} \mathrm{X}_{1}+\mathrm{b}_{2} \mathrm{X}_{2}+\mathrm{b}_{3} \mathrm{X}_{3+\mathrm{e}}
$$


Di mana:

Y : Kinerja karyawan

a : Konstanta

e : Variabel regresi

$\mathrm{X}_{1} \quad$ : Proses rekrutmen

$\mathrm{X}_{2} \quad$ : Pengaturan staf

$\mathrm{X}_{3} \quad$ : Pengembangan karir

Adapun hasil perhitungan regresi (dengan bantuan program SPSS for windows) dapat dilihat pada tabel 4.16 berikut ini.

Tabel 4.5 Hasil Analisis Koefisien Regresi Linier Berganda

\begin{tabular}{|c|c|c|c|c|}
\hline Variabel & $\begin{array}{l}\text { Koefi } \\
\text { sien } \\
\text { Regr } \\
\text { esi } \\
\text { (b) }\end{array}$ & $\mathbf{t}$ & Sig. $t$ & Hasil \\
\hline Rekrutmen $\left(\mathrm{X}_{1}\right)$ & $\begin{array}{l}0,50 \\
4\end{array}$ & 2,176 & $\mathbf{0 , 0 3 9}$ & Signifikan \\
\hline $\begin{array}{l}\text { Pengaturan } \\
\text { staf }\left(X_{2}\right)\end{array}$ & $\begin{array}{l}- \\
0,42 \\
5\end{array}$ & $\begin{array}{l}- \\
1,378\end{array}$ & 0,180 & $\begin{array}{c}\text { Tidak } \\
\text { Signifikan }\end{array}$ \\
\hline $\begin{array}{l}\text { Pengembangan } \\
\text { Karir }\left(\mathrm{X}_{3}\right)\end{array}$ & $\begin{array}{l}0,19 \\
8\end{array}$ & 0,754 & 0,457 & $\begin{array}{c}\text { Tidak } \\
\text { Signifikan }\end{array}$ \\
\hline Constanta & 0,016 & & & \\
\hline $\begin{array}{l}\mathrm{R}^{2}=\mathbf{0 , 4 3 9} \\
\text { Adjusted R Squa } \\
\mathbf{0 , 0 9 9} \\
\text { F }_{\text {hitung }=\mathbf{2 , 0 6 4}} \\
\text { Sig. F }=\mathbf{0 , 1 3 0}\end{array}$ & & & & \\
\hline
\end{tabular}

Sumber: Data primer diolah

Dari tabel tersebut di atas, dapat diturunkan persamaan regresi sebagai berikut:

$\mathrm{Y}=0.016+0,504 \mathrm{X}_{1}+(-0,425) \mathrm{X}_{2}+0,198 \mathrm{X}_{3}$

Secara simultan, variabel bebas yang terdiri dari rekrutmen, pengaturan staf dan pengembangan karir berpengaruh terhadap kinerja karyawan di Sekolah Tinggi Ilmu Manajemen Indonesia (STIMI) Banjarmasin, koefisien determinasi $\left(\mathrm{R}^{2}\right)=0,439$ memberi arti bahwa tiga variabel bebas tersebut memberikan konstribusi sebesar 43,9\% terhadap kinerja karyawan Sekolah Tinggi Ilmu Manajemen Indonesia (STIMI) Banjarmasin.

Untuk menguji keabsahan persamaan regresi yang berkaitan dengan hipotesis yang diajukan, akan diuji dengan uji $\mathrm{F}$ dan uji t. Adapun tahapan pengujiannya sebagai berikut:

a. Hasil Uji F ( $\left.F_{\text {test }}\right)$

Uji ini digunakan untuk mengetahui apakah variabel bebas secara bersama-sama berpengaruh secara signifikan terhadap variabel terikat. Ataupun untuk mengetahui apakah model regresi dapat dipergunakan untuk memprediksi apakah variabel terikat atau tidak.

Dari tabel 4.16 diketahui $\mathrm{F}_{\text {hitung }}$ 2,064 lebih kecil dari $\mathrm{F}_{\text {tabel }}=2,09$, maka $\mathrm{H}_{0}$ diterima yang artinya tidak ada pengaruh secara signifikan antara rekrutmen, pengaturan staf dan pengembangan karir terhadap kinerja karyawan Sekolah Tinggi Ilmu Manajemen Indonesia (STIMI) Banjarmasin. Dari hasil analisis tersebut maka hipotesa pertama yang diajukan dapat dibuktikan.

b. Hasil Uji t

Uji ini digunakan untuk mengetahui apakah dalam model regresi variabel bebas secara parsial berpengaruh signifikan terhadap variabel terikat.

Pengujian secara parsial masing-masing atas variabel bebas terhadap variabel terikat dapat dijelaskan sebagai berikut: 
1) Proses Rekrutmen

Hasil analisis diperoleh nilai probabilitas signifikansi t sebesar 0,039 yang lebih kecil dari 0,05 . Nilai $t_{\text {hitung }}$ sebesar 2,176 lebih besar dari $t_{\text {tabel }}$ sebesar 1,98, berarti $\mathrm{H}_{0}$ ditolak dan $\mathrm{H}_{\mathrm{a}}$ diterima, artinya variabel rekrutmen $\left(\mathrm{X}_{1}\right)$ berpengaruh terhadap kinerja karyawan Sekolah Tinggi Ilmu Manajemen Indonesia (STIMI) Banjarmasin.

2) Pengaturan staf

Hasil analisis diperoleh nilai probabilitas signifikansi t sebesar 0,180 yang lebih besar dari 0,05 . Nilai $t_{\text {hitung }}$ sebesar $-1,378$ lebih kecil dari $t_{\text {tabel }}$ sebesar 1,98 , berarti $\mathrm{H}_{0}$ diterima dan $\mathrm{H}_{\mathrm{a}}$ ditolak, artinya variabel pengaturan staf $\left(\mathrm{X}_{2}\right)$ tidak berpengaruh terhadap kinerja karyawan Sekolah Tinggi Ilmu Manajemen Indonesia (STIMI) Banjarmasin.

3) Pengembangan Karir

Hasil analisis diperoleh nilai probabilitas signifikansi t sebesar 0,457 yang lebih besar dari 0,05. Nilai thitung sebesar 0,754 lebih besar dari tabel sebesar 1,98 , berarti $\mathrm{H}_{0}$ ditolak dan $\mathrm{H}_{\mathrm{a}}$ diterima, artinya variabel pengembangan karir $\left(\mathrm{X}_{3}\right)$ berpengaruh terhadap kinerja karyawan Sekolah Tinggi Ilmu Manajemen Indonesia (STIMI) Banjarmasin.

a. Variabel Rekrutmen $\left(\mathrm{X}_{1}\right)$

Berikut ini tabel 4.4.hasil pengolahan data statistik untuk masing-masing item pernyataan distribusi frekuensi tanggapan responden tentang variabel Rekrutmen.

Tabel 4.6 Distribusi Frekuensi Variabel Rekrutmen $\left(\mathrm{X}_{1}\right)$

\begin{tabular}{|c|c|c|c|c|c|c|c|c|c|c|c|c|}
\hline \multirow{3}{*}{ Indikator } & \multicolumn{10}{|c|}{ Skor Jawaban Responden } & \multirow{3}{*}{$\begin{array}{l}\text { Rata- } \\
\text { rata }\end{array}$} & \multirow{3}{*}{$\begin{array}{l}\text { To } \\
\text { tal }\end{array}$} \\
\hline & \multicolumn{2}{|c|}{1} & \multicolumn{2}{|l|}{2} & \multicolumn{2}{|l|}{3} & \multicolumn{2}{|l|}{4} & \multicolumn{2}{|l|}{5} & & \\
\hline & $\mathrm{F}$ & $\%$ & $\mathrm{~F}$ & $\%$ & $\mathrm{~F}$ & $\%$ & $\mathrm{~F}$ & $\%$ & $\mathrm{~F}$ & $\%$ & & \\
\hline $\mathrm{X} 11$ & - & - & - & - & 1 & 3,3 & 20 & 66,7 & 9 & 30 & 4,27 & \\
\hline $\mathrm{X} 12$ & - & - & - & - & - & - & 22 & 73,3 & 8 & 26,7 & 4,27 & \\
\hline X13 & - & - & 2 & $\begin{array}{l}6, \\
7\end{array}$ & 1 & 3,3 & 19 & 63,3 & 8 & 26,7 & 4,1 & \\
\hline X14 & - & - & - & - & 1 & 3,3 & 16 & 53,3 & $\begin{array}{l}1 \\
3\end{array}$ & 43,3 & 4,4 & 4,19 \\
\hline $\mathrm{X} 15$ & - & - & - & - & 6 & 20 & 16 & 53,3 & 8 & 26,7 & 4,07 & \\
\hline $\mathrm{X} 16$ & - & - & 1 & $\begin{array}{l}3, \\
3\end{array}$ & 4 & $\begin{array}{l}13, \\
3\end{array}$ & 17 & 56,7 & 8 & 26,7 & 4,07 & \\
\hline X17 & - & - & - & - & 2 & 6,7 & 20 & 66,7 & 8 & 26,7 & 4,2 & \\
\hline
\end{tabular}

Sumber: Data primer diolah (2018)

Berdasarkan indikator-indikator rekrutmen tersebut, data hasil jawaban responden menyatakan bahwa responden cenderung setuju $(3,96)$ atas pernyataan-pernyataan pada Proses Rekrutmen yang dilakukan oleh Sekolah Tinggi Ilmu Manajemen Indonesia (STIMI) Banjarmasin.

b. Variabel Pengaturan $\operatorname{Staf}\left(\mathrm{X}_{2}\right)$

Masing-masing indikator variabel pengaturan staf dapat dilihat pada tabel 4.5 distribusi frekuensi tanggapan responden tentang pengaturan staf.

Tabel 4.7 Distribusi Frekuensi Variabel Pengaturan $\operatorname{Staf}\left(\mathrm{X}_{2}\right)$

\begin{tabular}{|c|c|c|c|c|c|c|c|c|c|c|c|c|}
\hline \multirow{3}{*}{$\begin{array}{l}\text { Indi } \\
\text { kato } \\
\text { r }\end{array}$} & \multicolumn{10}{|c|}{ Skor Jawaban Responden } & \multirow{3}{*}{$\begin{array}{l}\text { Rata- } \\
\text { rata }\end{array}$} & \multirow{3}{*}{ Total } \\
\hline & \multicolumn{4}{|c|}{\begin{tabular}{l|l}
1 & 2
\end{tabular}} & \multicolumn{2}{|l|}{3} & \multicolumn{2}{|l|}{4} & \multicolumn{2}{|l|}{5} & & \\
\hline & $\mathrm{F}$ & $\%$ & $\mathrm{~F}$ & $\%$ & $\mathrm{~F}$ & $\%$ & $\mathrm{~F}$ & $\%$ & $\mathrm{~F}$ & $\%$ & & \\
\hline $\mathrm{X} 21$ & - & - & - & - & - & - & 20 & 66,7 & 10 & 33,3 & 4,33 & \multirow{6}{*}{4,18} \\
\hline $\mathrm{X} 22$ & - & - & - & - & 1 & 3,3 & 15 & 50 & 14 & 46,7 & 4,43 & \\
\hline $\mathrm{X} 23$ & -1 & - & 1 & 3,3 & 7 & 23,3 & 18 & 60 & 4 & 13,3 & 3,83 & \\
\hline $\mathrm{X} 24$ & - & - & - & - & 1 & 3,3 & 22 & 73,3 & 7 & 23,3 & 4,2 & \\
\hline $\mathrm{X} 25$ & - & - & - & - & 10 & 33,3 & 13 & 43,3 & 7 & 23,3 & 3,9 & \\
\hline $\mathrm{X} 26$ & - & - & 1 & 3,3 & - & - & 20 & 66,7 & 9 & 30 & 4,23 & \\
\hline
\end{tabular}




\begin{tabular}{|l|l|l|l|l|l|l|l|l|l|l|l|}
\hline X27 & - & - & 1 & 3,3 & 6 & 20 & 14 & 46,7 & 9 & 30 & 4,03 \\
\hline X28 & - & - & - & - & 2 & 6,7 & 18 & 60 & 10 & 33,3 & 4,27 \\
\hline X29 & - & - & - & - & 6 & 20 & 17 & 56,7 & 7 & 23,3 & 4,03 \\
\hline $\begin{array}{l}\text { X21 } \\
0\end{array}$ & - & - & - & - & 3 & 10 & 22 & 73,3 & 5 & 16,7 & 4,07 \\
\hline $\begin{array}{l}\text { X21 } \\
1\end{array}$ & - & - & - & - & - & - & 18 & 60 & 12 & 40 & 4,4 \\
\hline $\begin{array}{l}\text { X21 } \\
2\end{array}$ & - & - & - & - & 1 & 3,3 & 22 & 73,3 & 7 & 23,3 & 4,2 \\
\hline $\begin{array}{l}\text { X21 } \\
3\end{array}$ & - & - & - & - & - & - & 19 & 63,3 & 11 & 36,7 & 4,37 \\
\hline $\begin{array}{l}\text { X21 } \\
4\end{array}$ & - & - & - & - & 3 & 10 & 17 & 56,7 & 10 & 33,3 & 4,23 \\
\hline
\end{tabular}

Berdasarkan indikator-indikator pengaturan staf tersebut, data hasil jawaban responden menyatakan bahwa responden cenderung setuju $(4,18)$ atas pernyataan-pernyataan pada Pengaturan staf (Staffing)yang dilakukan oleh Sekolah Tinggi Ilmu Manajemen Indonesia (STIMI) Banjarmasin.

c. Variabel Pengembangan Karier $\left(\mathrm{X}_{3}\right)$

Masing-masing indikator variabel pengembangan karir dapat dilihat pada tabel 4.6 distribusi frekuensi tanggapan responden tentang pengembangan karir.

Tabel 4.8 Distribusi Frekuensi Variabel Pengembangan Karir $\left(\mathrm{X}_{3}\right)$

\begin{tabular}{|c|c|c|c|c|c|c|c|c|c|c|c|c|}
\hline \multirow{3}{*}{ Indikator } & \multicolumn{10}{|c|}{ Skor Jawaban Responden } & \multirow{3}{*}{ Rata-rata } & \multirow{3}{*}{ Total } \\
\hline & \multicolumn{4}{|c|}{\begin{tabular}{|l|l|}
1 & 2 \\
\end{tabular}} & \multicolumn{2}{|c|}{3} & \multicolumn{2}{|l|}{4} & \multicolumn{2}{|l|}{5} & & \\
\hline & $\bar{F}$ & $\%$ & $\bar{F}$ & $\%$ & $\mathrm{~F}$ & $\%$ & $F$ & $\%$ & $F$ & $\%$ & & \\
\hline X31 & - & - & 1 & 3,3 & 2 & 6,7 & 22 & 73,3 & 5 & 16,7 & 4,03 & \multirow{5}{*}{4,23} \\
\hline $\mathrm{X} 32$ & - & - & - & - & 2 & 6,7 & 21 & 70 & 7 & 23,3 & 4,17 & \\
\hline $\mathrm{X} 33$ & - & - & - & - & - & - & 18 & 60 & 12 & 40 & 4,4 & \\
\hline X34 & - & - & - & - & 3 & 10 & 20 & 66,7 & 7 & 23,3 & 4,13 & \\
\hline $\mathrm{X} 35$ & - & - & - & - & 1 & 3,3 & 15 & 50 & 14 & 46,7 & 4,43 & \\
\hline
\end{tabular}

Berdasarkan indikator-indikator pengembangan karir tersebut, data hasil jawaban responden menyatakan bahwa responden cenderung setuju $(4,23)$ atas pernyataan-pernyataan pada pengembangan karir yang dilakukan oleh Sekolah Tinggi Ilmu Manajemen Indonesia (STIMI) Banjarmasin.

d. Variabel Kinerja Karyawan (Y)

Masing-masing indikator variabel kinerja karyawan dapat dilihat pada tabel 4.7 distribusi frekuensi tanggapan responden tentang kinerja karyawan.

Tabel 4.9 Distribusi Frekuensi Variabel Kinerja Karyawan (Y)

\begin{tabular}{|c|c|c|c|c|c|c|c|c|c|c|c|c|}
\hline \multirow{3}{*}{ Indikator } & \multicolumn{10}{|c|}{ Skor Jawaban Responden } & \multirow{3}{*}{ Rata-rata } & \multirow{3}{*}{ Total } \\
\hline & \multicolumn{2}{|l|}{1} & \multicolumn{2}{|l|}{2} & \multicolumn{2}{|l|}{3} & \multicolumn{2}{|l|}{4} & \multicolumn{2}{|l|}{5} & & \\
\hline & $\mathrm{F}$ & $\%$ & $\mathrm{~F}$ & $\%$ & $\mathrm{~F}$ & $\%$ & $\mathrm{~F}$ & $\%$ & $\mathrm{~F}$ & $\%$ & & \\
\hline Y1 & - & - & - & - & 8 & 26,7 & 22 & 73,3 & - & - & 3,73 & \multirow{5}{*}{3,84} \\
\hline Y2 & - & - & - & - & 5 & 16,7 & 16 & 53,3 & 9 & 30 & 4,13 & \\
\hline Y3 & - & - & - & - & 3 & 10 & 22 & 73,3 & 5 & 16,7 & 4,07 & \\
\hline Y4 & - & - & 2 & 6,7 & 10 & 33,3 & 18 & 60 & - & - & 3,53 & \\
\hline Y5 & - & - & 1 & 3,3 & 7 & 23,3 & 21 & 70 & 1 & 3,3 & 3,73 & \\
\hline
\end{tabular}

Berdasarkan indikator-indikator kinerja karyawan tersebut, data hasil jawaban responden menyatakan bahwa responden cenderung setuju $(3,84)$ atas pernyataan-pernyataan pada kinerja karyawan yang dilakukan oleh Sekolah Tinggi Ilmu Manajemen Indonesia (STIMI) Banjarmasin. 
Hasil analisis model regresi di atas menunjukkan bahwa variabel proses rekrutmen, pengaturan staf, dan pengembangan karir berpengaruh signifikan terhadap kinerja karyawan Sekolah Tinggi Ilmu Manajemen Indonesia (STIMI) Banjarmasin.

Gambaran tentang kinerja karyawan Sekolah Tinggi Ilmu Manajemen Indonesia (STIMI) Banjarmasin dikategorikan menjadi tiga item. Dari ketiga item tersebut, karyawan memilih pengembangan karir dengan nilai rata-rata sebesar 4,23. Item tersebut yang paling besar di antara ratarata item yang lainnya.

Berdasarkan hasil uji t menunjukkan dari ketiga variabel bebas yang diamati dalam penelitian ini terbukti bahwa variabel proses rekrutmen, pengaturan staf, dan pengembangan karir berpengaruh terhadap kinerja karyawan Sekolah Tinggi Ilmu Manajemen Indonesia (STIMI) Banjarmasin. Hal ini dikarenakan ketiga variabel tersebut sangat dipertimbangkan oleh karyawan. Kebijakan proses rekrutmen dapat berubah sesuai dengan kebijakan dari pimpinan dengan melihat kondisi kebutuhan pegawai pada institusi Sekolah Tinggi Ilmu Manajemen Indonesia (STIMI) Banjarmasin.

Variabel pengaturan staf merupakan variabel yang kurang diperhatikan oleh karyawan, karena karyawan dengan posisi pekerjaan yang sudah ditentukan berdasarkan kemampuan dan keahliannya tentu akan memiliki kinerja yang lebih baik, lebih memahami tugas dan tanggung jawabnya.

Pengembangan karir merupakan variabel yang penting dalam diri karyawan, dalam menentukan perkiraan perubahan arah karirnya, tetapi bukan berarti harus merubah karir yang ada atau berhenti sama sekali dari posisi pekerjaan yang sudah dijalani.

Variabel proses rekrutmen berpengaruh signifikan terhadap kinerja karyawan Sekolah Tinggi Ilmu Manajemen Indonesia (STIMI) Banjarmasin. Berdasarkan hal ini maka variabel proses rekrutmen akan menjadi bahan pertimbangan dalam mengambil keputusan untuk pengembangan sumber daya manusia di Sekolah Tinggi Ilmu Manajemen Indonesia (STIMI) Banjarmasin.

\section{Kesimpulan}

Berdasarkan pembahasan pada bab-bab sebelumnya maka dapat ditarik kesimpulan dari penelitian tentang proses rekrutmen, pengaturan staf, dan pengembangan karir terhadap kinerja karyawan Sekolah Tinggi Ilmu Manajemen Indonesia (STIMI) Banjarmasin adalah:

1. Variabel proses rekrutmen, pengaturan staf, dan pengembangan karir berpengaruh besar terhadap kinerja karyawan Sekolah Tinggi Ilmu Manajemen Indonesia (STIMI) Banjarmasin adalah variabel pengembangan karir karyawan.

2. Dari ketiga variabel proses rekrutmen, pengaturan staf, dan pengembangan karir, variabel yang sangat dominan adalah proses rekrutmen yang mempengaruhi kinerja karyawan Sekolah Tinggi Ilmu Manajemen Indonesia (STIMI) Banjarmasin.

Berdasarkan hasil penelitian ini ada beberapa saran yang dapat penulis berikan dan perlu dipertimbangkan bagi pihak yang berkepentingan:

1. Bagi Sekolah Tinggi Ilmu Manajemen Indonesia (STIMI) Banjarmasin diharapkan dengan mengetahui variabel yang berpengaruh dominan yaitu proses rekrutmen dalam menentukan kebijakan, strategi dan langkah secara umum maupun khusus di bidang sumber daya manusia.

2. Bagi peneliti lainnya dapat lebih mengembangkan penelitian dengan menggunakan variabel lainnya, misal variabel kompensasi, kepemimpinan, sikap rekan kerja, motivasi dan lainnya, bahkan bisa ditambahkan dengan variabel kebijakan dari pimpinan untuk menentukan keputusan dalam mengembangkan Sekolah Tinggi Ilmu Manajemen Indonesia (STIMI) Banjarmasin khususnya di bidang sumber daya manusia. 


\section{REFERENSI}

Badriyah, Mila. 2015. Manajemen Sumber Daya Manusia.Pustaka Setia: Bandung

Cut Zurnali. 2010. KnowledgeWorker: Kerangka Riset Manajemen Sumber Daya Manusia Masa Depan. Penerbit Unpad Press: Bandung

Fahmi, Irham. 2013. Manajemen Kinerja (Teori dan Aplikasi). CV. Alfabeta: Bandung

Fathoni, Abdurrahmat. 2006. Manajemen Sumber Daya Manusia. PT. Rineka Cipta: Jakarta

Hariandja, Marihot Tua Efendi. 2005. Manajemen Sumber Daya Manusia: Pengadaan, Pengembangan, Pengkompensasian, dan Peningkatan Produktivitas Pegawai Cetakan ketiga. PT Grasindo: Jakarta

Hasibuan, Malayu S.P. 2007. Manajemen Sumberdaya Manusia (Edisi Revisi). Jakarta: PT. Bumi Aksara

Mangkunegara, AA. Anwar Prabu. 2005. Evaluasi Kinerja Sumber Daya Manusia. PT. Rineka Aditama: Bandung

Mondy, R. Wayne. 2008. Manajemen Sumber Daya Manusia. Penerbit Erlangga: Jakarta

Nawawi, Hadari. 2005. Manajemen Sumber Daya Manusis untuk Bisnis yang Kompetitif.Gadjah Mada University Press: Yogyakarta

PB, Triton. 2010. Manajemen Sumber Daya Manusia: Persfektif Partnership dan Kolektivitas. PT. Suka Buku: Jakarta

Rachmawati, Ike Kusdyah. 2008. Manajemen Sumber Daya Manusia. Penerbit Andi: Yogyakarta

Rivai, Veithzal. 2013. Manajemen Sumber Daya Manusia untuk Perusahaan (dari Teori ke Praktik).PT. Rajagrafindo Persada: Jakarta

Saydam, Gouzali, (2000). Manajemen Sumber Daya Manusia: Suatu pendekatan Mikro (Dalam Tanya Jawab) Cetakan kedua. Djambatan: Jakarta

Siagian, Sondang P. 2006. Manajemen Sumber Daya Manusia, Cetakan ketiga belas. Bumi Aksara: Jakarta

Sulistiyani, Ambar Teguh \& Rosidah, 2003, Manajemen Sumber Daya Manusia. Graha Ilmu: Yogyakarta

Susilo, Willy. 2002. Audit Sumber Daya Manusia (Panduan Komprehensif Auditor dan Praktisi Manajemen Sumber Daya Manusia serta Pimpinan Organisasi / Perusahaan. PT. Vorqistatama Binamega. 